\title{
VESIJÄRVEN JA TAMMISTON AIKAISEN SUHTAUTUMISESTA PERUNAVIROOSEIHIN.
}

\author{
Veikko Brummer. \\ Hankkijan kasvinjalostuslaitos, Tammisto.
}

Saapunut 15. 1. 1949 .

Kaikkialla maassamme, varsinkin keski- ja pohjoisosissa yleisesti viljelty Vesijärviperuna on vanha englantilainen jaloste Harbinger, joka tuli kauppaan jo v. 1894 (8). Hankkijan kasvinjalostuslaitoksen perunakokeissa Tammistossa lajike on ollut 25 vuotta (vv. 1923—47); vasta äskettäin se jouduttiin hylkäämään virustautialttiutensa takia. Toinen hyvin pitkään kokeissa ollut lajike on Tammiston Aikainen, ainoa kotimainen perunajaloste. Se polveutuu risteytyksestä Up to date $\times$ Prof. Edler ja tuli kauppaan v. 1930 (9). Tammiston Aikainen, joka on ollut vertailevissa perunakokeissa vuodesta 1927 lähtien, on osoittautunut varsin arvokkaaksi vertailulajikkeeksi monille kokeiltavina olleille varhaislajikkeille lähinnä sen vuoksi, että se ainakin Tammiston kokeissa, missä virustaudit ovat 1930-luvulta lähtien esiintyneet sangen yleisinä (1), on osoittautunut harvinaisen kestäväksi näitä tauteja vastaan. Nimenomaan vertailu Vesijärven ja Tammiston Aikaisen kesken on tästä syystä muodostunut kiintoisaksi.

Ensimmäinen kenttäkirjamerkintä Vesijärven tautisuudesta on vuodelta 1926 , jolloin kasvustossa oli havaittu jokunen virustautinen yksilö, arviolta n. $1 \%$. Kesti kuitenkin useita vuosia, ennenkuin lajikkeen satoisuus alkoi virustautien takia jyrkästi laskea (taul. 1). Vuonna 1934 oli Vesijärvessä kenttäkirjamerkinnän mukaan jo paljon tautisia yksilöitä. Uutta, tervettä koesiementä hankittiin vasta v. 1938, jolloin Vesijärven suhteellinen satoluku (90) nousi vuosien 1927-33 tasolle laskeakseen kuitenkin jo heti seuraavana vuonna alemmaksi kuin koskaan aikaisemmin. Sadon alentumisen syynä oli viiruviroosi, jonka saastuttamia yksilöitä oli $89 \%$, kesällä 1939 suorittamieni havaintojen mukaan. Paitsi Vesijärveä, todettiin mainittuna vuonna, jolloin kirjoittaja sai perunakokeet hoitoonsa, monet muutkin kokeissa olleista lajikkeista virustautien saastuttamiksi. Näitä tauteja ja eri perunalajikkeiden alttiutta ryhdyttiin nyt lähemmin tutkimaan. Vesijärvi ja Tammiston Aikainen joutuivat erikoisesti tutkimuskohteiksi sen vuoksi, että niiden suhtautuminen virustauteihin oli niin suuresti toisistaan poikkeava. Valitettavasti sotavuodet häiritsivät tutkimusten suorittamista suunnitelmien mukaisesti. 
Taulukko 1. Vesijärven ja Tammiston Aikaisen satovertailu Tammistossa 1927-39.

Table 1. Comparison between Harbinger and Tammisto Early at Tammisto 1927-39.

\begin{tabular}{ccccc}
\hline \hline $\begin{array}{c}\text { Vuosi } \\
\text { The year }\end{array}$ & $\begin{array}{c}\text { Tammiston Aikainen } \\
\text { t/ha } \\
\text { Tammisto Early } \\
\text { tons/har }\end{array}$ & $\begin{array}{c}\text { Vesijärvi } \\
\text { t/ha } \\
\text { Harbinger } \\
\text { tons/har }\end{array}$ & $\begin{array}{c}\text { Vesijärvi } \\
\text { erotus } \\
\text { Harbinger } \\
\text { differencs }\end{array}$ & $\begin{array}{c}\text { Suhdeluku } \\
\text { T:n Aik. t/ha }=100 \\
\text { Rel. fig. T. Early } \\
\text { tons/har }=\text { Ioo }\end{array}$ \\
\hline 1927 & 36.9 & & & 84 \\
-28 & 32.3 & 31.0 & -5.9 & 90 \\
-29 & 29.7 & 29.2 & -3.1 & 102 \\
-30 & 26.5 & 30.3 & +0.6 & 92 \\
-31 & 20.8 & 24.3 & -2.2 & 96 \\
-32 & 15.0 & 19.9 & -0.9 & 103 \\
-33 & 32.7 & 15.5 & -0.5 & 87 \\
-34 & 34.3 & 28.4 & -11.1 & 68 \\
-35 & 33.8 & 23.2 & -13.1 & 61 \\
-36 & 34.2 & 20.7 & -8.7 & 75 \\
-37 & 25.6 & 25.5 & -7.7 & 70 \\
-38 & 20.4 & 17.9 & $(-2.1)$ & $(90)$ \\
-39 & 31.1 & $(18.3)^{1}$ & -17.7 & 43 \\
\hline
\end{tabular}

Katsaus sääoloihin.

Sääolot ovat tarkasteltavina olevien 22 vuoden kuluessa (1927-48) vaihdelleet melkoisesti. Taulukossa 2 on esitetty kasvukauden eri kuukausien lämpö- ja sademäärät poikkeamina normaalista. Paremman yleiskatsauksen saamiseksi perunan kasvulle ja virustautien leviämiselle tärkeimpien kesäkuukausien (VI-VIII) sääoloista, on näiltä kolmelta kuulta esitetty lämpötila- ja sadepoikkeamien summat.

Todetaan, että ainoastaan vuodet 1928 ja 1929 ovat kesäkuukausiltaan olleet poikkeuksellisen viileitä, 1931 ja 1942 ovat olleet normaalisia ja muut kaikki normaalia lämpimämpiä, erikoisesti 1930-luvun loppuvuodet (1936-39). Sadeoloissa on havaittavissa melko selvää jaksottaisuutta. Niinpä vuodet $1931-34$ ja 1937 -42 sekä 1946 —47 ovat olleet kesäkuukausiltaan hyvin vähäsateisia. Runsassateisen jakson taas muodostavat vuodet 1943-45 sekä 1928 - 30. Lämpö- ja sadeoloilla on selvästi havaittava vaikutus virustautien esiintymisrunsauteen, kuten myöhemmin tullaan näkemään.

Vertailtavana olevien perunalajikkeiden suhtautuminen virooseihin.

Vesijärviperunassa esiintynyt viroosi on tautikuvan perusteella luettu kuuluvaksi viiruviroosiin, vaikka siinä ei lehtisuonissa ja lehdistössä esiinnykään tyypillisessä viiruviroosissa tavattavia mustanruskeita viiruja tai kuoliolaikkuja, ns.

\footnotetext{
1 Siemen uusittu - Seed renewed.
} 
nekrooseja. Viiruviroosin aiheuttajana on Y-virus (Solanum virus 2), jonka tiedetään voivan aiheuttaa erilaisen tautikuvan eri lajikkeissa $(2,11)$. Tautiset yksilöt voi helposti eroittaa jo kohta taimelle tulon jälkeen. Ne ovat terveitä matalakasvuisempia ja tulevat loppukesällä tavallisesti rentovartisiksi. Lehdet ovat ryppyisiä ilman mitään selviä värilaikkuja eli klorooseja (kuva 1). Tämän tapaista virustautia on meillä aikaisemmin nimitetty ryppyviroosiksi (10). Keskikesällä

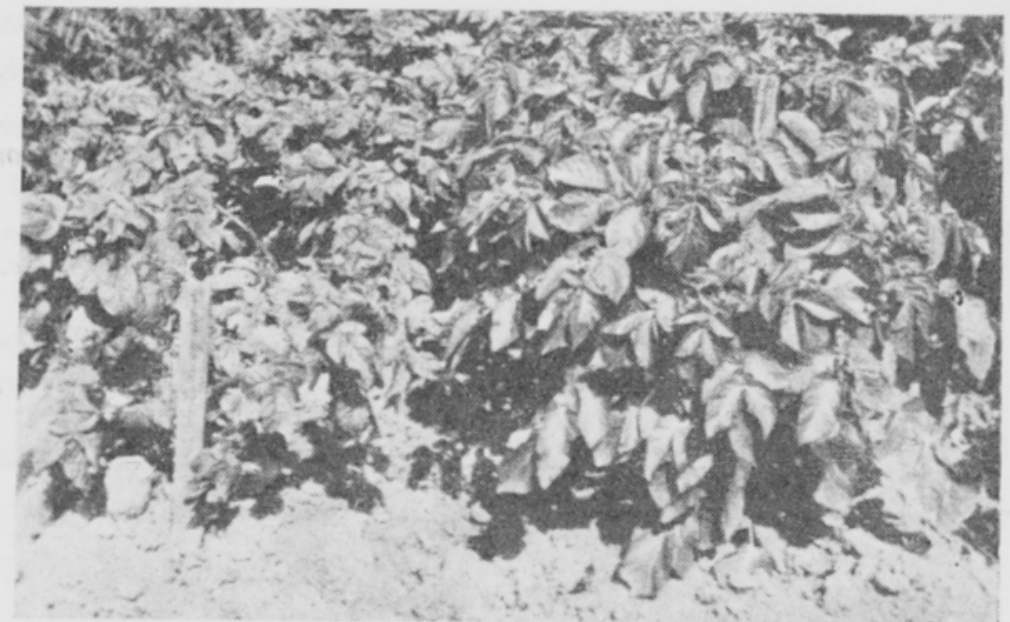

Kuva 1. Vasemmalla primääristä viiruviroosia Tammistossa jatkuvasti viljeltävänä olleessa Vesijärviperunassa. Oikealla Karilasta saatua tervettä kantaa.

Fig. I. On the left primary streak in Harbinger potato aftercultivated at Tammisto. On the right healthy Harbiger from Karila.

saattaa Vesijärvessä tavata edellä kuvatusta jossain määrin poikkeavaa viroosia (kuva 2). Yksilöissä, jotka alkukesästä ovat olleet täysin terveitä ja kasvultaan normaaleja, käyvät lehdet ryppyisiksi, niihin ilmestyy suuria kuoliolaikkuja ja lehdet alkavat katkeilla tyvestä jääden kuihtuvina roikkumaan pitkin vartta, kuten useasti tyypillisessä viiruviroosissa. Seuraavana vuonna kehittyy tällaisten yksilöiden mukuloista virustautisia yksilöitä, jotka ovat samankaltaisia kuin alussa kuvatut. Ensimmäisen vuoden (tartuntakesän) tautikuva, ns. sekundäärinen viroosi on siis vähän toisenlainen kuin mukuloissa kulkeutuvan viruksen aiheuttama primäärinen viroosi.

Viiruviroosin Vesijärviperunassa aiheuttamista satotappioista on Tammistossa suoritettu yksilötutkimuksia, joista osa on jo aikaisemmin julkaistu (1). Täydennykseksi esitetään vielä tulokset vuodelta 1940, jolloin tutkittiin sekä primäärisen, että sekundäärisen viiruviroosin vaikutusta (taul. 3). Kolmena vuonna $(1939,-40,-42)$ suoritettujen tutkimusten mukaan oli primäärisesti tautisteı yksilöiden sato keskim. vain n. $32 \%$ terveiden yksilöiden sadosta, vaihdellen eri vuosina $22-43 \%$. Sekundäärisen viiruviroosin aiheuttama sadon vähennys on jäänyt virherajojen sisälle, kuten taulukosta 3 käy selville.

Viruksen levittäjinä kysymykseen tulevista hyönteisistä ei Tammistossa ole suoritettu yksityiskohtaisempia tutkimuksia. Voidaan kuitenkin mainita, että kesällä 1947 löysi maist. O. HEIKINHEIMo peruna-aineistosta erästä kirvalajia Doralis rhamni BOYER DE FOnse, jonka mm. Ruotsissa suoritetuissa kokeissa (7) on todettu voivan levittää Y-virusta.

Määrättyinä kesinä, jolloin ilmeisesti sääolot ovat viruksia levittävien hyönteisten esiintymiselle hyvin suotuisat, saattaa Vesijärviperunan kasvuaikana tapahtuva saastuminen olla hyvin voimakasta. Niinpä kesällä 1947 kasvoi koekentällä Vesijärveä, josta edellisenä kesänä oli poistettu mahdollisimman tarkoin kaikki virustautiset yksilöt. Poistokertoja oli $3 .(9 / 7,19 / 7$ ja $17 / 8)$ ja tautisina poistettiin 
Taulukko 2. Kasvukauden sääolot Tammistossa 1927-48.

Table 2. Weather conditions at Tammisto during the growing seasons 1927-48.

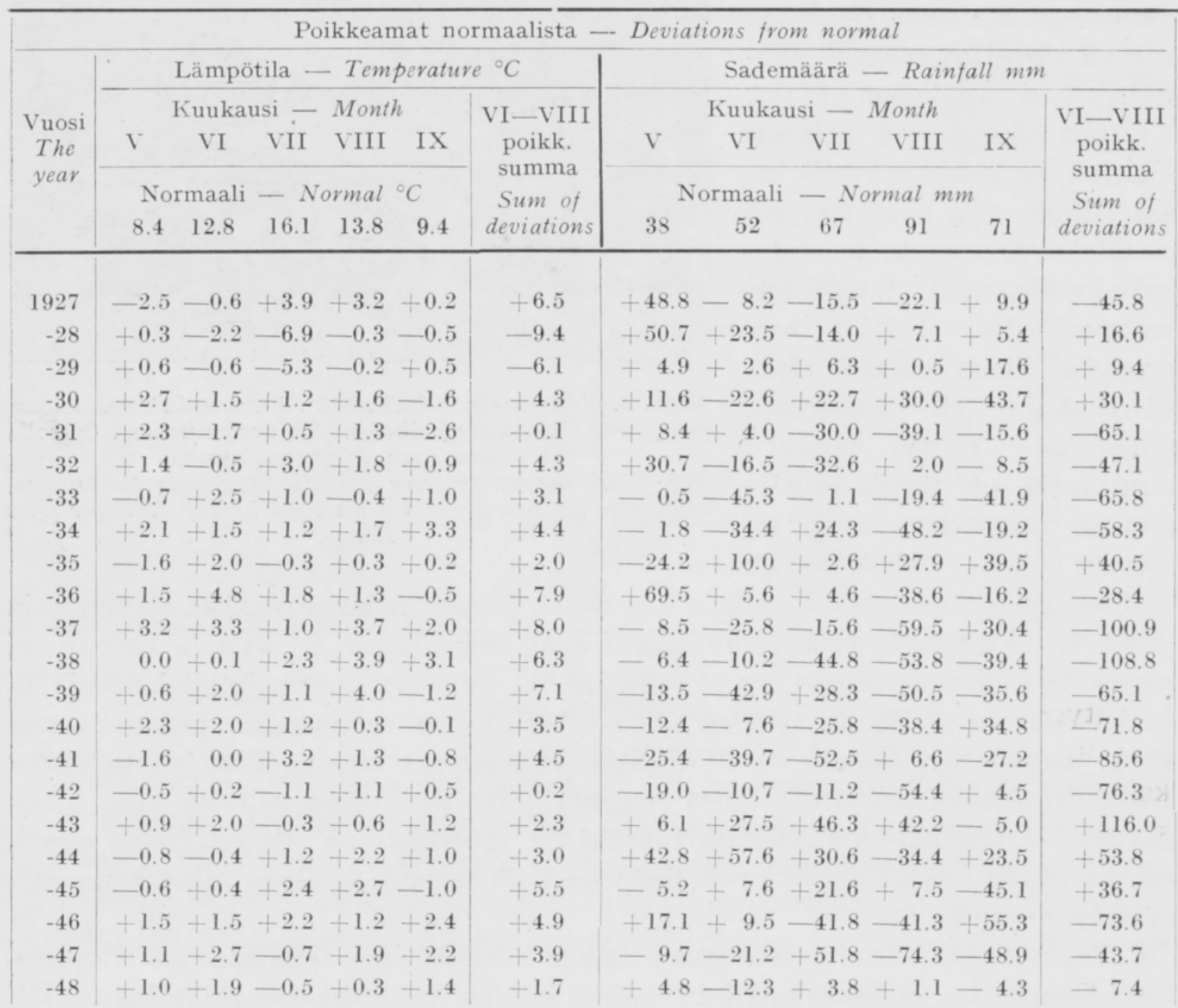

$63 \%$ yksilöistä ( $52 \%$ prim. $+11 \%$ sekund. viiruviroosia). Kesällä 1947 oli 18/7 kasvustossa virustautisia yksilöitä $60 \%$ ja $25 / 8$ olivat kaikki yksilöt saastuneet. Samantapainen tulos saatiin kesällä 1940. Edellisenä kesänä oli kasvustosta, jossa oli $89 \%$ virustautisia, valittu terveiltä näyttäviä yksilöitä. Näistä peräisin olevassa aineistossa oli $5 / 890 \%$ virustautisia ( $84 \%$ prim. $+6 \%$ sekund. viiruviroosia). Tautisten yksilöiden poistaminen, ns. negatiivinen valinta ei pahoin saastuneen Vesijärviperunan suhteen ole Tammiston olosuhteissa johtanut tyydyttävään tulokseen johtuen tämän lajikkeen virustautialttiudesta ja viruksien suotuisista leviämisedellytyksistä. Negatiivisella valinnalla voidaan saavuttaa tyydyttäviäkin tuloksia (6), jos lähtöaineisto ei ole kovin tautista eikä virusten leviäminen ole erityisen voimakasta.

Virustautien esiintymisestä Tammiston Aikaisessa voidaan monivuotisten havaintojen perusteella tehdä johtopäätös, että lajike ilmeisesti on suuressa määrin vastustuskykyinen niitä vastaan. Onko kysymyksessä luontainen kestävyys tai ns. toleranssi (vert. KöHLER (5)), mikä on todennäköisempää, ei saastutusko- 
keiden puuttuessa ole ratkaistavissa. Virustautisten yksilöiden määrittäminen tässä lajikkeessa on ollut hyvin vaikeaa, koska taudin oireet, milloin sellaisia on ollut havaittavissa, ovat yleensä olleet hyvin lieviä ja epämääräisiä. Joinakin kuivina kesinä on ollut aihetta epäillä, että ko. lajikkeen kasvusto on kenties läpikotaisin virustautista, koska terveiden ja tautisiksi epäiltyjen yksilöiden välille on ollut vaikea vetää mitään varmaa rajaa. Tautikuvan perusteella lienee Tammiston Aikaisessa esiintyvää virustautia lähinnä pidettävä hyvin lievänä kurttuviroosina (1). Mitään Vesijärveen verrattavaa jyrkkää satoisuuden alentumista ei Tammiston Aikaisen kohdalla ole ollut havaittavissa. Myös muilla koepaikoilla tehtyjen havaintojen mukaan (3) on Tammiston Aikainen todettu kestäväksi ja Vesijärvi araksi virustaudeille.

Tammiston Aikaisessa on kuitenkin aivan viime vuosina todettu eräs toinen varsistotauti, näivetystauti (Verticillium alboatrum REINKE $\mathcal{E}$ BERTH). Tämänkään taudin määrittäminen ei

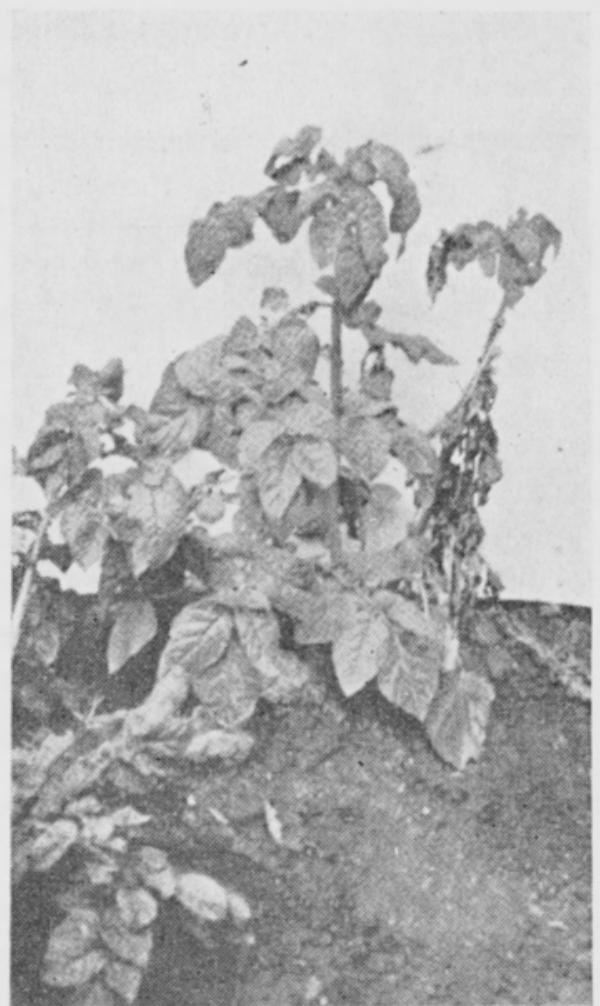

Kuva 2. Sekundääristä viiruviroosia Vesijärviperunassa.

Fig. 2. Secondary streak in Harbinger potato. kaikkina vuosina ole ollut mahdollista, joko siitä syystä, ettei sitä ole esiintynyt, tai sitten on voimakas lehtiruttosaastunta, joskus myös aikaisen tuleentumisen aiheuttama varsiston kuihtuminen tehnyt sen toteamisen vaikeaksi. Taudin oireet näkyvät yleensä selvimpinä vasta elokuun puolella. Näivetystautisen yksilön lehdet ovat vaalean vihreät tai kellertävät ja lehdykät ovat kääntyneet reunoiltaan ylöspäin. Koskettaessa ne tuntuvat veltoilta. Taudin loppuvaiheessa lehdet riippuvat kuivina pitkin vartta, joka myös usein kuivuu. Lehtien käyristyminen alkaa ylälehdistä. Lievemmissä tapauksissa on vain osa yksilön versoista sairaita, muiden näyttäessä täysin terveiltä. Varren tyven poikkileikkauksessa ovat tautisten yksilöiden varsien johtojänteet ruskeahtavat. Näivetystautisen yksilön mukuloissa, joskaan ei aina kaikissa, näkyy pitkittäisleikkauksessa napapäästä lähtevä ja joskus silmupäähän asti ulottuva ruskea rengas vähän matkaa kuoren alapuolella.

Näivetystaudin aiheuttamista satotappioista on suoritettu yksilötutkimuksia kahtena vuonna (taul. 4). Tautisten yksilöiden sato on ollut n. $70 \%$ terveiden sadosta. Mukulan keskipaino on tautisilla yksilöillä ollut pienempi kuin terveillä, samoin mukulan koko, kuten lajittelutulokset selvästi osoittavat.

Tutkimukset näivetystaudin esiintymisestä Tammiston peruna-aineistossa ovat vielä keskeneräiset. Selvittämistä kaipaa lähinnä, minkä vuoksi tautisten yksilöiden määrä vaihtelee niin paljon ei ainoastaan eri viljelyksillä, vaan myös saman pellon eri osissa, vaikka on käytetty samaa siemenperunaa. Näivetystautisten yksilöiden määrä on talousviljelyksillä vaihdellut likimain $20-80 \%$, koekentällä 
Taulukko 3. Yksilötutkimuksia Vesijärviperunasta 1940.

Table 3. Individual studies of Harbinger potato 1940.

\begin{tabular}{|c|c|c|c|c|c|c|c|}
\hline $\begin{array}{l}\text { Yksilö } \\
\text { Plant }\end{array}$ & $\begin{array}{l}\text { Tutkittuja } \\
\text { yksilöitä } \\
\text { Number of } \\
\text { studied } \\
\text { plants }\end{array}$ & $\begin{array}{l}\text { Mukul: } \\
\text { Tuber } \\
\mathrm{g}\end{array}$ & $\begin{array}{l}\text { asato } \\
\text { yield } \\
\text { sl } \\
\text { Rel.fig. }\end{array}$ & $\begin{array}{c}\text { Mukulan } \\
\text { paino } \\
\text { Tuber } \\
\text { weight } \\
\text { g }\end{array}$ & $\begin{array}{l}\text { Mukula- } \\
\text { luku } \\
\text { Number } \\
\text { of } \\
\text { tubers }\end{array}$ & $\begin{array}{l}\text { Verso- } \\
\text { luku } \\
\text { Number } \\
\text { of } \\
\text { sprouts }\end{array}$ & $\begin{array}{c}\text { Korkeus } \\
\text { Height } \\
\mathrm{cm}\end{array}$ \\
\hline Terve - Healthy ${ }^{1}$ & 20 & $867 \pm 38$ & 100 & 51 & 17.2 & 4.6 & 46 \\
\hline $\left.\begin{array}{l}\text { Prim. viiruviroosinen } \\
\text { Prim. streak diseased }\end{array}\right\}$ & 20 & $377 \pm 35$ & 43 & 48 & 7.9 & 4.0 & 40 \\
\hline $\left.\begin{array}{l}\text { Sekund. } \\
\text { Second. }\end{array}\right\}$ & 20 & $827 \pm 62$ & 95 & 48 & 17.3 & 4.0 & 46 \\
\hline & $\cdots$ & $\begin{array}{l}\text { Satoero } \\
\text { Difference }\end{array}$ & \multicolumn{3}{|c|}{$\begin{array}{c}\text { Erotuksen luotettavuus } \mathrm{P} \\
P \text { for difference }\end{array}$} & & \\
\hline $\begin{array}{l}\text { Terve - prim. viiruviroosi } \\
\text { Healthy - prim. streak }\end{array}$ & & $490 \pm 52$ & \multicolumn{3}{|c|}{0.001} & & \\
\hline $\begin{array}{l}\text { Terve - sekund. viiruviroosi } \\
\text { Healthy - second. streak }\end{array}$ & & $40 \pm 73$ & \multicolumn{3}{|c|}{0.6} & & \\
\hline $\begin{array}{l}\text { Sekund. - prim. viiruviroosi } \\
\text { Second. - prim. streak }\end{array}$ & & $450 \pm 71$ & \multicolumn{3}{|c|}{0.001} & & \\
\hline
\end{tabular}

Taulukko 4. Yksilötutkimuksia Tammiston Aikaisesta 1946 ja 1948.

Table 4. Individual studies of Tammisto Early potato 1946 and 1948.

\begin{tabular}{|c|c|c|c|c|c|c|c|c|c|}
\hline \multirow{2}{*}{$\begin{array}{l}\text { Yksilö } \\
\text { Plant }\end{array}$} & \multirow{2}{*}{$\begin{array}{l}\text { Tutkittuja } \\
\text { yksilöitä } \\
\text { Number of } \\
\text { studied } \\
\text { plants }\end{array}$} & \multicolumn{2}{|c|}{$\begin{array}{l}\text { Mukulasato } \\
\text { Tuber yield }\end{array}$} & \multirow{2}{*}{$\begin{array}{c}\text { Mukulan } \\
\text { paino } \\
\text { Tuber } \\
\text { weight } \\
\text { g }\end{array}$} & \multirow{2}{*}{\multicolumn{2}{|c|}{$\begin{array}{c}\text { Mukula- } \\
\text { luku } \\
\text { Number } \\
\text { of } \\
\text { tubers }\end{array}$}} & \multicolumn{3}{|c|}{$\begin{array}{c}\text { Lajittelu- } \% \\
\text { Percentage of sorting }\end{array}$} \\
\hline & & $\mathrm{g}$ & $\begin{array}{c}\mathrm{sl} \\
\text { Rel.fig. }\end{array}$ & & & & $\underset{4 \mathrm{~cm}}{<}$ & $\begin{array}{c}4-5 \quad 1 / 2 \\
\mathrm{~cm}\end{array}$ & $\overrightarrow{51 / 2}_{\mathrm{cm}}$ \\
\hline \multicolumn{10}{|c|}{ Vuosi l } \\
\hline Terve - Healthy & 30 & $478 \pm 29$ & 100 & 49 & 9.8 & 28. & $3 \pm 2.63$ & $64.6 \pm 3.55$ & $7.1 \pm 2.30$ \\
\hline $\begin{array}{l}\text { Näivetystautinen } \\
\text { Verticillium diseased }\end{array}$ & 30 & $335 \pm 21$ & 71 & 38 & 8.7 & 45. & $.7 \pm 3.85$ & $51.7 \pm 3.93$ & $2.6 \pm 1.81$ \\
\hline Erotus - Difference & & $143 \pm 36$ & & & & -17 & $.4 \pm 4.66$ & $12.9 \pm 5.30$ & $4.5 \pm 2.93$ \\
\hline $\left.\begin{array}{l}\text { Erotuksen luotettavuus } \mathrm{P} \\
P \text { for difference }\end{array}\right\}$ & & 0.001 & & & & & 0.001 & 0.02 & 0.2 \\
\hline & & Vuosi & $1948-$ & The year & 1948 & & & & \\
\hline Terve - Healthy & 30 & $965 \pm 33$ & 100 & 65 & 14.9 & 16. & $1 \pm 1.52$ & $46.2 \pm 3.34$ & $37.7+3.41$ \\
\hline $\begin{array}{l}\text { Näivetystautinen } \\
\text { Verticillium diseased }\end{array}$ & 30 & $656 \pm 36$ & 68 & 44 & 15.1 & 37 . & $.9 \pm 0.97$ & $52.3 \pm 0.92$ & $9.8+2.42$ \\
\hline Erotus - Difference & & $309 \pm 49$ & & & & -21 . & $.8 \pm 1.80$ & $-6.1 \pm 3.47$ & $27.9+4.18$ \\
\hline $\begin{array}{l}\text { Erotuksen luotettavuus } \mathrm{P} \\
P \text { for difference }\end{array}$ & & 0.001 & & & & & .091 & 0.1 & 0.001 \\
\hline
\end{tabular}

1 Terveet yksilöt ovat peräisin keväällä 1940 Etelä-Savon koeasemalta saadusta Vesijärvestä, tautiset sen sijaan Tammistossa kasvaneesta kannasta.

The healthy plants are originate in Harbinger get from Etelä-Savo Experiment Station in the spring 1940, the diseased plants instead are originate in Tammisto cultivated Harbinger. 
se on ollut huomattavasti alhaisempi $(0.4-17 \%)$. Vesijärviperunassa ei näivetystautia ole havaittu.

\section{Alkuperä- ja jatkoviljelyskokeet.}

Vuodesta 1940 lähtien on Vesijärven ja Tammiston Aikaisen vertailussa ollut mukana eri Vesijärvi-kantoja ja vuodesta 1943 lähtien myös Tammiston Aikaisen eri kantoja. Tutkimuskohteena on ollut paitsi alkuperän, myös Tammistossa tapahtuneen jatkoviljelyn vaikutus ko. lajikkeen ja kannan satoisuuteen ja terveyteen. Vertailulajikkeena on koko ajan ollut jatkuvasti vuodesta toiseen kokeissa kasva-

Taulukko 5. Vesijärven ja Tammiston Aikaisen alkuperäkoe 1941.

Table 5. Trial with Harbinger and Tammisto Early of different origins 1941.

\begin{tabular}{|c|c|c|c|c|c|}
\hline \multirow{2}{*}{$\begin{array}{l}\text { Siemenperunan alkuperä }{ }^{1} \\
\text { Origin of seed potatoes }\end{array}$} & \multicolumn{3}{|c|}{$\begin{array}{l}\text { Mukulasato } \\
\text { Tuber yield }\end{array}$} & \multirow{2}{*}{$\begin{array}{c}\text { Istutusmukulan } \\
\text { keskipaino } \\
\text { Mean weight of } \\
\text { seed tubers } \\
\mathrm{g}\end{array}$} & \multirow{2}{*}{$\begin{array}{l}\text { Virustautisia } \\
\text { yksilöitä \% } \\
\text { Percentage of } \\
\text { virus disea- } \\
\text { sed plants }\end{array}$} \\
\hline & $\begin{array}{c}\text { t/ha } \\
\text { tons/har }\end{array}$ & $\begin{array}{c}\text { erotus } \\
\text { Differ- } \\
\text { ence }\end{array}$ & $\begin{array}{l}\text { sl } \\
\text { Rel.fig. }\end{array}$ & & \\
\hline
\end{tabular}

Vesijärvi - Harbinger

Tammisto (Karila -38)

1) (Karila -40)

Leteensuo

12.9

100

97

Tohmajärvi

14.7

$+1.8$

59

50

Tohmajär
Pälkäne

20.3

$+7.4$

114

55

19.6

$+6.7$

87

32

Karila

16.9

$+4.0$

66

21

Maaninka

19.6

$+6.7$

152

66

45

Ruukki

19.1

$+6.2$

152

Apukka

13.4

$+0.5$

160

Tammiston Aikainen - Tammisto Early

Tammisto

Piikkiö

Leteensuo

Tohmajärvi

Karila

Maaninka

Apukka

\section{5}

23.6

23.6

25.7

25.5

25.0

24.5

$\begin{array}{rr} & 100 \\ +4.1 & 121 \\ +4.1 & 121 \\ +6.2 & 132 \\ +6.0 & 131 \\ +5.5 & 128 \\ +5.0 & 126\end{array}$

55

68

55

67

70

63

63

5
5
1
7
5
9
5

Erotuksen luotettavuus $\mathrm{P}-P$ for difference 0.001

Pienin luotettava (P 0.05) satoero - Significance $(P 0.05) 2.89 \mathrm{t} / \mathrm{ha}$

${ }^{1}$ Leteensuo $=$ Suoviljelysyhdistyksen Leteensuon koeasema - Finnish Bog Cultivation Society's Experiment Station at Leteensuo; Tohmajärvi = Suovilj. yhd. Tohmajärven koeasema - FBCS's Experiment Station at Tohmajärvi; Pälkäne = Pohjois-Hämeen kasvinviljelyskoeasema — Pohjois-Häme Exp. Station at Pälkäne; Karila = Etelä-Savon k.k. - Etelä-Savo Exp. Station at Karila; Maaninka = Pohjois-Savon k.k. - Pohjois-Savo Exp. Station at Maaninka; Ruukki = Pohjois-Pohjanmaan k.k. - Pohjois-Pohjanmaa Exp. Station at Ruukki; Apukka = Perä-Pohjolan k.k. - Perä-Pohjola Exp. Station at Apukka; Piikkiö = Maatalouskoelaitos, puutarhaosasto - Agricultural Research Institute, Depart. of Horticulture at Piikkiö. 
Taulukko 6. Tuloksia Vesijärven jatkoviljelyskokeista $1938-46$.

Table 6. Results with aftercultivated Harbinger 1938-46.

Lajike ja alkuperä

Variety and origin
Tammiston Aikaisen (mittari) mukulasato $\mathrm{t} /$ ha sekä Vesijärven mukulasatojen poil keamat mittarista. Suluissa () virustautisten yksilöiden $\%$-määrät kasvustossa

Tuber yield of Tammisto Early (standard) and deviations of Harbinger from standas in tons/har. In brackets () percentage of virus diseased plants

$\begin{array}{lllllllll}1938 & 1939 & 1940 & 1941 & 1942 & 1943 & 1944 & 1945 & 1946\end{array}$

\section{Tammiston Aikainen \\ Tammisto Early}

20.4

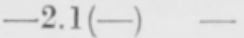

19.5

27.3

25.3

27.2

22.2

23.1

Vesijärvi, Karila orig.

Harbinger, " original

1. jatkoviljelys

Ist after-cultivation

2. 2nd

3. 3rd is

4. 4 th

5. $5^{t h}$ i)

6. 6 th

Erotuksen luotettavuus $\mathrm{P}$

$P$ for difference

Pienin luot. satoero $\mathrm{t} / \mathrm{ha}$

Significance tons/har
$-2.1(-) \quad-\quad-6.7(7)+0.1(37)+7.4(13)-5.5(4)$

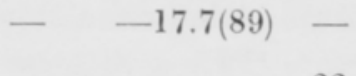

$-4.8(50)-$

$+3.7(4)-4.3(-) \quad-$

$\begin{array}{ll}- & - \\ - & -\end{array}$

0.05

0.001

0.05

0.001

0.001

0.001

0.01

0.001

0.001

$\begin{array}{llllllll}2.13 & 3.81 & 7.36^{1} & 2.89 & 3.87 & 2.63 & 2.13 & 1.71\end{array}$

nut Tammiston Aikainen, josta ei koko koeaikana ole poistettu tautisia yksilöitä, kuten ei muistakaan Tammiston Aikaisen kasvustoista. Toista alkuperää oleva koesiemen on saatu etupäässä Etelä-Savon kasvinviljelyskoeasemalta Karilasta. Siemenperuna on saapunut Tammistoon tavallisesti keväällä ja on idätetty samanaikaisesti muun koesiemenen kanssa. Istutusmukuloiden painoa ei kaikkina vuosina ole määritetty. Tammiston ja Karilan siemenen koossa ei ole ollut mitään huomattavia eroja, paitsi v. 1941. Jotta virustautien vaikutus tulisi selvempänä esille, ei myöskään Vesijärvestä ole poistettu tautisia yksilöitä. Suoritetuista iajittelukokeista (1, p. 179) on käynyt selville, ettei lajittelulla voida poistaa kuin osa virustautisista yksilöistä peräisin olevaa perunaa siemenperunalajitteena käytetyn perunan $\left(4-5 \frac{1}{2} \mathrm{~cm}\right)$ joukosta.

Kesällä 1941 oli järjestetty laajempi alkuperäkoe, jossa verrattiin useilta eri kasvinviljelyskoeasemilta saatua Tammiston Aikaista ja Vesijärveä vastaaviin Tammistossa kasvaneisiin lajikkeihin. Tulokset on esitetty taulukossa 5. Kokeen arvoa vähentää jossain määrin siemenperunoiden erilainen koko. Ilmeistä kuitenkin on, että nimenomaan myös siemenperunan alkuperällä ja kasvuston terveyden tilalla on ollut osuutensa satoeroihin. Tammistossa kasvaneen perunan sato on kummankin lajikkeen kohdalta ollut kaikkein pienin. Merkillisen poikkeuksen tästä tekee vain pohjoisimman koeaseman Vesijärvi. Virustautihavainnot ovat tottumattoman henkilön tekemiä. Vesijärven osalta niitä voitanee kuitenkin pitää melko luotettavina, koska tautisten yksilöiden määrittely on tässä lajikkeessa verraten helppoa.

1 Vain 2 kertausruutua - Only two replications 
Taulukko 7. Yhdistelmä edellisestä taulukosta.

Table 7. Summary of foregoing table.

\begin{tabular}{|c|c|c|c|c|}
\hline \multirow{2}{*}{$\begin{array}{l}\text { Lajike ja alkuperä } \\
\text { Variety and origin }\end{array}$} & \multirow{2}{*}{$\begin{array}{l}\text { Koevuodet } \\
\text { Trial years }\end{array}$} & \multicolumn{2}{|c|}{$\begin{array}{l}\text { Mukulasato } \\
\text { Tuber yield }\end{array}$} & \multirow{2}{*}{$\mathrm{P}$} \\
\hline & & $\begin{array}{l}\mathrm{t} / \mathrm{ha} \\
\text { tons/har }\end{array}$ & $\begin{array}{c}\text { sl } \\
\text { Rel.fig. }\end{array}$ & \\
\hline T:n Aikainen - Tammisto Early & $1938-41$ & 28.5 & 100 & \\
\hline Vesijärvi - Harbinger, Karila 1938 & " & $-12.2 \pm 4.74$ & 57 & 0.1 \\
\hline T:n Aikainen - Tammisto Early & $1940-46$ & 26.8 & 100 & \\
\hline Vesijärvi - Harbinger, Karila 1940 & " & $-5.8 \pm 1.09$ & 78 & 0.01 \\
\hline T:n Aikainen - Tammisto Early & $1942-46$ & 25.0 & 100 & \\
\hline Vesijärvi — Harbinger, Karila 1942 & $"$ & $+0.7 \pm 7.95$ & 103 & 0.5 \\
\hline T:n Aikainen - Tammisto Early & $1943-46$ & 24.5 & 100 & \\
\hline Vesijärvi — Harbinger, Karila 1943 & n & $-3.9 \pm 1.03$ & 84 & 0.05 \\
\hline Vesijärvi — Harbinger, Karila 1942 & $1942-46$ & 25.7 & 100 & \\
\hline ") & n & $-6.5 \pm 2.87$ & 75 & 0.1 \\
\hline Vesijärvi — Harbinger, Karila 1942 & $1943-46$ & 23.5 & 100 & \\
\hline จ 1943 & $\Rightarrow$ & $-2.9 \pm 2.49$ & 88 & 0.4 \\
\hline Vesijärvi — Harbinger, Karila 1943 & $1943-46$ & 20.6 & 100 & \\
\hline (1) 1940 & " & $-0.9 \pm 1.67$ & 96 & 0.7 \\
\hline
\end{tabular}

Taulukko 8. Tuloksia Tammiston Aikaisen jatkoviljelyskokeista 1941, 1943 -48. Table 8. Results with after-cultivated Tammisto Early 1941, 1943-48.

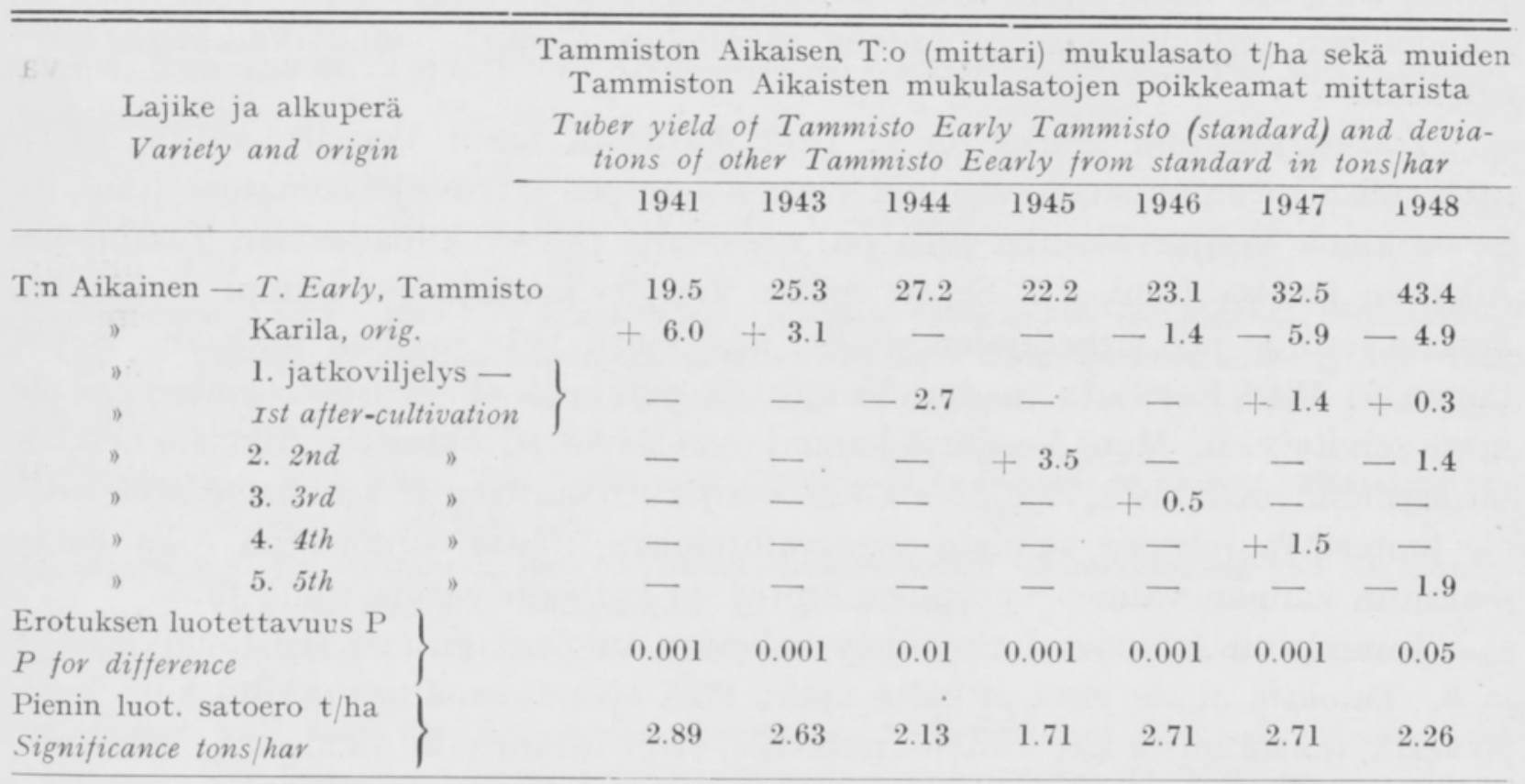

Sotavuodet ehkäisivät kokeen jatkamisen suunnitellussa laajuudessa. EteläSavon koeasemalta, Karilasta hankittiin kuitenkin - joskaan ei aivan säännöllisesti - siemenperunaa, joten voitiin suorittaa vertailuja sen ja Tammistossa jatkoviljellyn siemenen välillä. Vesijärven osalta on tulokset esitetty taulukoissa 6 ja 7 . Ryhtymättä yksityiskohtaisemmin niitä selostamaan kiinnitetään seuraavassa huomiota vain muutamaan seikkaan. Verrattaessa toisiinsa virustautisten yksi- 
Taulukko 9. Yhdistelmä edellisestä taulukosta.

Table 9. Summary of foregoing table.

\begin{tabular}{|c|c|c|c|c|c|}
\hline \multirow{2}{*}{\multicolumn{2}{|c|}{$\begin{array}{l}\text { Lajike ja alkuperä } \\
\text { Variety and origin }\end{array}$}} & \multirow{2}{*}{$\begin{array}{l}\text { Koevuodet } \\
\text { Trial years }\end{array}$} & \multicolumn{2}{|c|}{$\begin{array}{l}\text { Mukulasato } \\
\text { Tuber yield }\end{array}$} & \multirow{2}{*}{$\mathrm{P}$} \\
\hline & & & $\begin{array}{c}\text { t/ha } \\
\text { tons/har }\end{array}$ & $\begin{array}{c}\text { sl } \\
\text { Rel.fig. }\end{array}$ & \\
\hline & Aikainen $-T$. Early, Tammisto & $1943-48$ & 29.0 & 100 & \\
\hline & " $\quad$ Karila 1943 & " & $+0.7 \pm 1.05$ & 102 & 0.6 \\
\hline & Aikainen - T. Early, Tammisto & $1946-48$ & 33.0 & 109 & \\
\hline & Karila 1946 & : & $-0.5 \pm 0.93$ & 98 & 0.7 \\
\hline \multirow[t]{2}{*}{$T: n$} & Aikainen $-T$. Early, Karila 1946 & $1946-48$ & .32 .5 & 100 & \\
\hline & " $\quad 1943$ & " = & $+0.5 \pm 0.72$ & 102 & 0.6 \\
\hline
\end{tabular}

löiden \%-lukuja (taul. 6) ja sääoloja valaisevaa taulukkoa (taul. 2), todetaan melko selvä vuorosuhde. Lämpiminä ja kuivina 1930-luvun loppuvuosina ja 1940-luvun alussa esiintyy runsaasti virustauteja ja jatkoviljellyn Vesijärven satoisuus alenee nopeasti. Vuodesta 1943 lähtien, jolloin alkoi vähän viileämpi ja hyvin runsassateinen jakso, virustautien määrä vähenee huomattavasti, eikä taantuminen ole läheskään niin nopeaa kuin aikaisempina vuosina, vieläpä satoisuus eräiden kantojen osalta mittarilajikkeeseen verrattuna paraneekin. Kun sademäärä v. 1946 jälleen laski huomattavasti alle normaalin, lisääntyivät virustaudit jälleen ja Vesijärven satoisuus laskee jyrkästi. Luonnollisesti Vesijärven ja Tammiston Aikaisen mahdollinen erilainen suhtautuminen sääoloihin on myös voinut vaikuttaa satotuloksiin.

Toinen kiintoisa seikka on v. 1942 Karilasta saatu Vesijärvi-kanta, jonka satoisuus alentuu huomattavammin vasta neljäntenä jatkoviljelysvuotena (taul. 6). Se on ainoa Vesijärvi-kanta, joka po. koeaikana pystyy kilpailemaan Tammiston Aikaisen kanssa (taul. 7). Se on muita Vesijärvikantoja satoisampi, vaikkakin keskim. erotus jää virherajojen sisälle, kun vuosi 1946 otetaan mukaan. Syytä tämän v. 1942 Karilasta saadun Vesijärven poikkeukselliseen satoisuuteen ei ole saatu selvitetyksi. Muut Vesijärvi-kannat ovat selvästi Tammiston Aikaista heikkosatoisempia. Karilasta v. 1938 saadun Vesijärven suhteen ei keskim. erotus tosin ole luotettava johtuen suurista vuosivaihteluista, mutta Tammiston Aikaisen ja mainitun kannan välinen vuotuinen erotus on kylläkin varma (taul. 6).

Tammiston Aikaisen jatkoviljelyskokeiden tulokset on esitetty taulukoissa 8 ja 9. Tuloksia ei ole yhtä pitkältä ajalta eikä aivan samoilta vuosilta kuin Vesijärvestä, mutta niistä käy kuitenkin selville, ettei Tammiston Aikaisessa ole havaittavissa mitään selvää taantumista. Jo yli pari vuosikymmentä Tammistossa kasvaneen Tammiston Aikaisen ja Karilasta saatujen kantojen kesken ei satoisuudessa ole ollut mitään luotettavia eroja (taul. 9). Karilasta saatu siemen kuten esim. Karila 1943, on joskus ollut Tammiston kantaa selvästi satoisampi (taul. 8), mutta 1. jatkoviljelysvuotena jäänyt viimemainittua heikommaksi. Jonain toisena vuonna on suhde saattanut olla päinvastainen, kuten esim. Karila 1947:ssä, tai ei ole ollut mitään varmaa eroa, kuten esim. Karila 1946:ssa. Tällaiset vaihtelut aiheutunevat, 
paitsi siemenperunan alkuperästä monine siihen vaikuttavine tekijöineen, kuten mm. Klapp (4) tutkimuksillaan on osoittanut, joskus ehkä myös koevirheistä, tai vaihteluista siemenperunan laadussa, kuten v. 1945, jolloin Tammiston kanta oli säilynyt talvivarastossa huomattavasti heikommin kuin Karila 1943. Näivetystauti on saattanut myös aiheuttaa odottamattomia eroja. Niinpä v. 1946, jolloin tauti ensimmäisen kerran havaittiin, oli Tammiston omassa kannassa $5 \%$ näivetystautisia yksilöitä ja muissa vain $1 \%$, kun sen sijaan v. 1948 näivetystautisia oli seuraavasti: Tammiston kanta 4 \%, Karila 19480.4 \%, Karila $19472 \%$, Karila 19468 \% ja Karila $194317 \%$. Virustautihavainnoista ei ole esitetty lukuja, koska taudin määritys on ollut siksi epämääräistä, ettei mitään varmoja \%-lukuja ole voitu laskea.

Edellä esitettyjen jatkoviljelyskokeiden tulokset olisivat erikoisesti Tammiston Aikaisen osalta kaivanneet täydennyksekseen muiltakin koepaikoilta kuin vain Etelä-Savon kasvinviljelyskoeasemalta Karilasta saatujen kantojen jatkoviljelyä Tammistossa. Kun kuitenkin otetaan huomioon, että alkuperäkokeessa (taul. 5) tältä koeasemalta peräisin olevat kannat sekä Vesijärvestä että Tammiston Aikaisesta kuuluivat parhaimpien joukkoon ja että mainittu koeasema on erikoistunut perunan koesiemenen viljelyyn paikalliskokeita vârten, ei kokeista saadut lopputulokset sittenkään liene vailla todistusvoimaa.

Tammistossa suoritettujen kokeiden perusteella voidaan päätellä, että Vesijärven ja Tammiston Aikaisen erilainen suhtautuminen virustauteihin on syynä siihen, että Vesijärvi Tammiston olosuhteissa viljeltynä taantuu näiden tautien vuoksi, kun taasen Tammiston Aikaisen sato-ominaisuudet säilyvät kutakuinkin muuttumattomina.

\section{KIRJALLISUUSLUETTELO.}

(1) Brummer, Veikko 1946. Tutkimuksia tärkeimmistä Tammistossa esiintyneistä perunavirooseista. Hankkijan kasvinjalostuslaitos Tammisto, Siemenjulkaisu 1946, p. 176-185.

(2) Esbo, Harald 1945. En del vanliga potatissorters reaktion mot vissa vira. Kungl. Lantbruksakad. Tidskr., 84, p. $299-313$.

(3) Jamalainen, E. A. 1946. The Significance of Potato Virus Diseases in Finland. Maataloustiet. Aikak., 18, p. 134-146.

(4) KLAPP, E. 1936. Zusammenhänge von Standortseigenschaften Viruserkrankung und Nachbauertrag der Kartoffel. Pflanzenbau, 12, p. 163-191.

(5) KöhleR, E. 1937. Die Resistenzzüchtung gegen den Kartoffelabbau im Lichte der Virusforschung. Der Züchter, 9, p. 13-15.

(6) Madsen, S. B. 1944. Om bekaempelse af Kartoflens Virussygdomme. Den Kgl. Veterinaer- og Landbohøjskoles Afdeling for Landbrugets Plantedyrkning, 23, p. 1-85.

(7) Ossiannilsson, FreJ 1947. Överföringsförsök med potatisens Y-virus genom bladlöss. Växtskyddsnotiser, N:r 5, p. 68-69.

(8) Salaman, Redcliffe N. 1926. Potato Varieties. Cambridge.

(9) Sauli, J. O. 1930. Selostus Tammiston uusimmista kauppaan lasketuista jalosteista. Hankkijan kasvinjalostuslaitos Tammisto, Siemenjulkaisu 1930, p. $180-183$.

(10) - 1943. Peruna. 2. painos. Helsinki.

(11) Whitehead, T., Mcintosh, T. P. and Findlay, W. M. 1945. The Potato in Health and Disease. Second Edition. Edinburgh. 
SUMMARY.

\section{ON SUSCEPTIBILITY TO THE VIRUS DISEASES OF HARBINGER AND TAMMISTO EARLY POTATOES.}

\section{VEIKKO BRUMMER.}

Tammisto, Plant Breeding Station of Hankkija:

The potato virus diseases have since the 30th decade of the 20th century during warm and dry growing seasons been very common in potato experiments at the Plant Breeding Station Tammisto. Especially the early varieties Harbinger, and Tammisto Early (a native improvement of a cross between Up to date and Prof. Edler) have been studied, because their susceptibility to the virus diseases was very different. Harbinger is susceptible to the streak, and therefore it will rather quickly degenerate at Tammisto. Tammisto Early again is obviously resistant, probably only tolerant to the virus diseases. The yielding capacity of the after-cultivated Tammisto Early remained nearly unchanged. This variety, however, seems to be susceptible to the Verticillium-disease. 